\title{
Non-volant small mammals (Rodentia and Didelphimorphia) diversity in an isolated area of the Serra da Mantiqueira, Minas Gerais state, Brazil \\ Diversidade de pequenos mamíferos não voadores (Rodentia e Didelphimorphia) em uma área isolada da Serra da Mantiqueira, Minas Gerais, Brasil
}

\author{
Michel Barros Farial (1) | Rayque de Oliveira Lanes" (1) | Cibele Rodrigues Bonvicino III \\ IInstituto Federal do Espírito Santo. Campus Alegre. Vitória, Espírito Santo, Brasil \\ "Universidade Federal do Rio de Janeiro. Pós-Graduação em Genética. Rio de Janeiro, Rio de Janeiro, Brasil \\ I"Instituto Nacional de Câncer. Divisão de Genética. Rio de Janeiro, Rio de Janeiro, Brasil
}

\begin{abstract}
The southeastern Atlantic Forest of the Zona da Mata Mineira is located in the extreme north of Minas Gerais state, Brazil. The Serra da Mantiqueira, is a mountainous region with a high diversity of small non-volant mammal species, several of which are rare species or endemic lineages. The presence of cryptic species in small mammals makes the karyotype an excellent tool for identification and detection of new lineages. We analyzed the karyotype of 14 species: 11 rodents Abrawayaomys ruschii, Akodon cursor, Blarinomys breviceps, Delomys sublineatus, Juliomys ossitenuis, Oligoryzomys nigripes, Oligoryzomys flavescens, Oxymycterus dasytrichus, Rhipidomys tribei, Sooretamys angouya, and Thaptomys nigrita; and three marsupials - Monodelphis scalops, Philander quica, and Marmosops incanus. We described for the first time the fundamental autosomal number and the morphology of sex chromosomes of Abrawayaomys ruschii, a rare sigmodontine species, and described a new karyotype for Blarinomys. The revision of published karyotypes of the species herein studied enabled the expansion of the geographic distribution of Oligoryzomys nigripes and Delomys sublineatus.
\end{abstract}

Keywords: Rodents. Marsupials. Chromosome complement. Geographic distribution.

Resumo: A Mata Atlântica do sudeste da Zona da Mata Mineira está situada no extremo norte da serra da Mantiqueira, estado de Minas Gerais, Brasil, sendo uma região de montanha, com alta diversidade de espécies de pequenos mamíferos não voadores, várias delas raras e endêmicas. A presença de espécies crípticas torna o cariótipo uma excelente ferramenta para identificação e detecção de novas linhagens. Foi analisado o cariótipo de 14 espécies de pequenos mamíferos não voadores: 11 roedores - Abrawayaomys ruschii, Akodon cursor, Blarinomys breviceps, Delomys sublineatus, Juliomys ossitenuis, Oligoryzomys nigripes, Oligoryzomys flavescens, Oxymycterus dasytrichus, Rhipidomys tribei, Sooretamys angouya e Thaptomys nigrita; e três marsupiais - Monodelphis scalops, Philander quica e Marmosops incanus. Descrevemos pela primeira vez o número fundamental autossômico e a morfologia dos cromossomos sexuais de Abrawayaomys ruschii, uma espécie rara de sigmodontíneos, e descrevemos um novo cariótipo para Blarinomys. A revisão de cariótipos publicados das espécies aqui estudadas permitiu ampliar a distribuição geográfica de Oligoryzomys nigripes e Delomys sublineatus.

Palavras-chave: Roedores. Marsupiais. Complemento cromossômico. Distribuição geográfica.

FARIA, M. B., R. O. LANES \& C. R. BONVICINO, 2020. Non-volant small mammals (Rodentia and Didelphimorphia) diversity in an isolated area of the Serra da Mantiqueira, Minas Gerais state, Brazil. Boletim do Museu Paraense Emílio Goeldi. Ciências Naturais 15(3): 643-662. DOI: http://doi.org/10.46357/bcnaturais.v15i3.203.

Autora para correspondência: Cibele Rodrigues Bonvicino. Instituto Nacional de Câncer. Divisão de Genética. CPQ. Rio de Janeiro, RJ, Brasil. CEP 20231-050 (cibele.bonvicino@gmail.com).

Recebido em 17/10/2019

Aprovado em 07/10/2020

Responsabilidade editorial: Alexandra Maria Ramos Bezerra
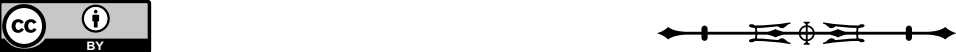


\section{INTRODUCTION}

Within the Neotropics the Atlantic Forest, South America, is considering a hotspot region with several endemic mammalian species. The southeastern region of the Atlantic Forest is formed by a topographical complex of mountains such as the Serra do Mar and Serra da Mantiqueira mountains, which directly influence this biome's landscapes (Costa, L. et al., 2000). These subparallel mountain systems are composed of the coastal Serra do Mar and the inland Serra da Mantiqueira, distributed along the continental Atlantic border. The Serra da Mantiqueira mountain range, formed by a mountainous area of rainforest vegetation (Ab'Saber, 1977), is about $500 \mathrm{~km}$ long, and spans three Brazilian states: São Paulo (30\%), Minas Gerais (60\%), and Rio de Janeiro (10\%). The Serra da Mantiqueira originated in the Paleocene, resulting in a complex of mountains with wide altitudinal variation (Almeida \& Carneiro, 1998), and its importance is highlighted in studies of the biogeographical history of different groups of small mammals (Costa, L. et al., 2000; Costa, B. et al., 2011; Faria et al., 2016; Leite, 2003). These studies point to the importance of this mountain range in the diversification of fauna in the region.

Non-volant small mammals, rodents belonging to the families of Cricetidae and Echimyidae and the marsupials of the family Didelphidae, account for $80 \%$ of the Atlantic Forest's endemic species, and are usually are the elements responsible for the regionalism of Neotropical mammal communities (Costa, L. et al., 2000). The subfamily Sigmodontinae encompasses a wide variety of forms and adaptive diversity (Patton et al., 2015), as well as the family Didelphidae (Gardner, 2008 [2007]).

Unfortunately, the levels of taxonomic differentiation of small mammal populations in the Atlantic Forest are still largely unknown to the majority of the genera, especially in the case of sigmodontine rodents. Although the subfamily Sigmodontinae has been studied for a long time (Hershkovitz, 1987), several species and genera have few specimens in scientific collections, e.g., Pseudoryzomys simplex, Phaenomys ferrugineus, Phyllomys lundi (Bonvicino et al., 2001b; Faria et al., 2016; Wolf et al., 2016), thus preventing important taxonomic, phylogenetic and biogeographic inferences. This situation is particularly worrying in view of the speed of destruction of unique environments in the Atlantic Forest, with 95\% of its original area having now become the most populous region of South America (Galindo-Leal \& Câmara, 2003). This high species diversity in the Neotropics can be attributed to forest refuges formed during the Pleistocene period (Haffer, 1969; Vanzolini \& Williams, 1970), with this forest refuge hypothesis explaining the Atlantic Forest's biodiversity and species endemism (Ab'Saber, 1977; Carnaval \& Moritz, 2008; Carnaval et al., 2009; Porto et al., 2012).

Among sigmodontine rodents this high diversity is underestimated due to the presence of morphologically similar species (Yazbeck et al., 2011). Although some species have chromosomal polymorphisms or variations (e.g., Holochilus chacarius in Nachman \& Myers, 1989, and Oligoryzomys nigripes in Bonvicino et al., 2001a), most of them are characterized by an essential constant chromosomal complement (e.g., species of the genera Calomys in Bonvicino et al., 2003, Juliomys in Paresque et al., 2009, Brucepattersonius and Oxymycterus in Bonvicino, 2011), thus making the karyotype an excellent tool for identifying species, especially small rodents where the presence of cryptic species is constant, in addition to undescribed species (Bonvicino et al., 2003; Paresque et al., 2009). Studies that integrate morphology, karyotype and DNA sequence data lead to an advance in knowledge about sigmodontinae rodents and Didelphimorphia marsupials, with a substantial increase in the number of recognized species (Gonçalves et al., 2005; Jansa \& Voss, 2000; Patton et al., 2000; Voss et al., 2005; Voss \& Jansa, 2009). However, few karyotypic studies integrate morphology and geographic distribution data into their analyses (Bonvicino et al., 2013; Weksler et al., 2017), and this has led to misidentification in the past. For example, the lack of integrated morphology and karyotype studies, 
led to the association of the same diploid number $(2 n)$ of 62 and fundamental autosomal number ( $\mathrm{FNa}$ ) of 64 with different co-generic species, Oligoryzomys eliurus and Oligoryzomys fornesi (Andrades-Miranda et al., 2001; Bonvicino \& Weksler, 1998), thus showing the importance of morphologic documentation in karyologic studies. In contrast to morphologic and molecular data, it is impossible to perform a retrospective analysis of karyotype, which also hampers karyological studies.

This study therefore aims to evaluate the chromosomal features and contribute to the debate on the species taxonomy and distribution of rodents and marsupials, including endemic species of the Zona da Mata Mineira, a hotspot mountain region in the Atlantic Forest biome. Herein, we karyotyped small mammals, and we discuss the karyotype variation of these species, and comment on the geographic distributions of the species surveyed.

\section{MATERIAL AND METHODS}

The study area is located in the municipality of Alto Jequitibá, Minas Gerais state, in the Atlantic Forest biome (Figure 1), and included two protected areas, classified as Reserva Particular de Patrimônio Natural (RPPN) category, in the Fazenda Harmonia (farm Harmonia). We carried out six field expeditions during one year in both areas, RPPN Santuário Ecológico Mata dos Jacus (-20.483404 S, -42.046899 W) and RPPN Refúgio dos Sauás (-20.407001S, $-42.041710 \mathrm{~W})$, both with semi-deciduous mountain vegetation (Veloso et al., 1991). In order to conduct inventories for the non-volant small mammals we placed Sherman and tomahawk live traps and one linear transect with 12 buckets (60 l), 10 meters apart, in each locality (Table 1). The study was conducted under permit number 41959-1 from the Instituto Chico Mendes de Conservação da Biodiversidade (ICMBio).

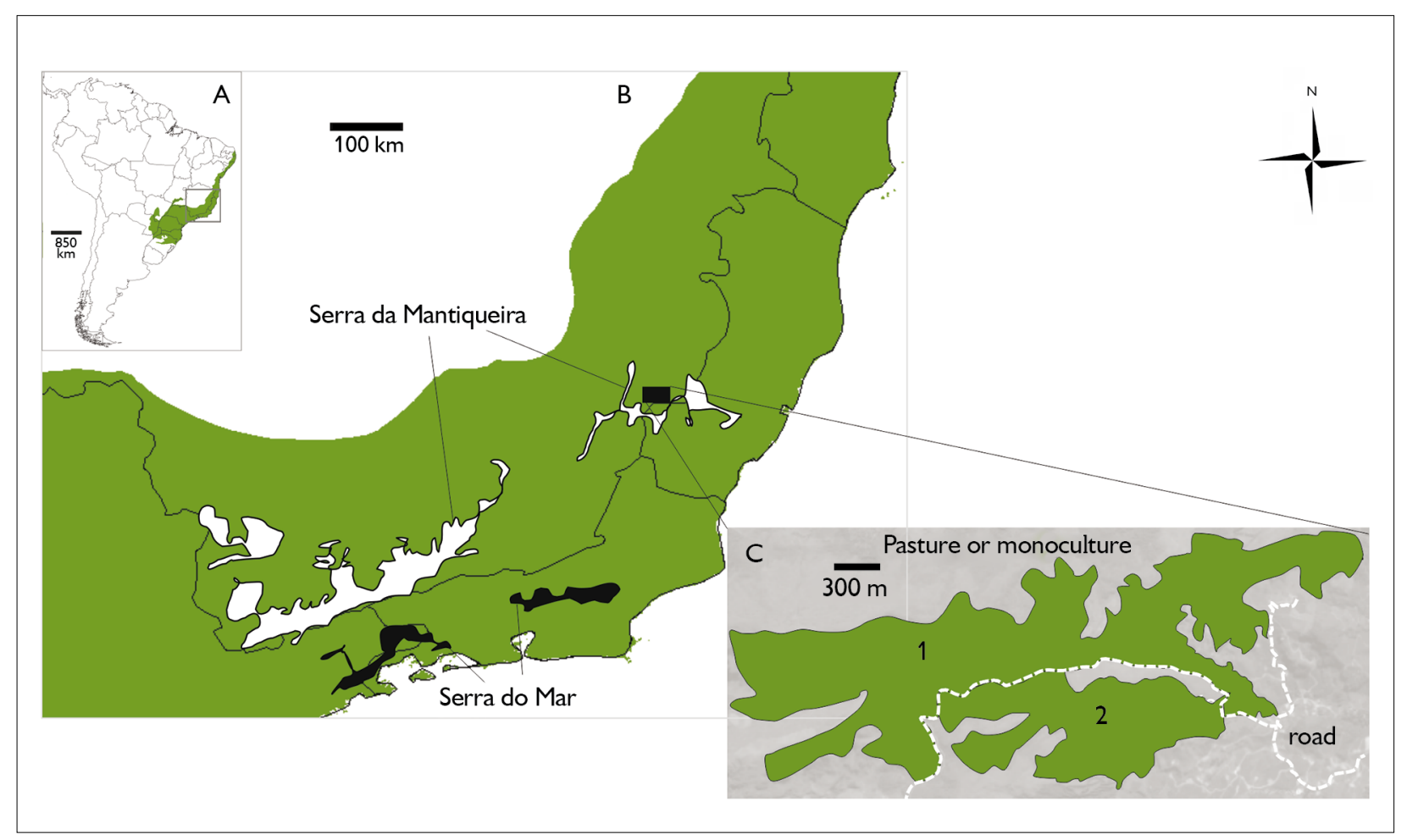

Figure 1. Locality of sampled area: A) South America map with Atlantic forest in green; B) Southeastern Brazil with Atlantic Forest (green), collecting locality (black rectangle), the highlands of the mountain range of Serra da Mantiqueira (white patches) and Serra do Mar (black patches); C) Collecting localities with RPPN Refúgio dos Jacus (1) and the RPPN Refúgio dos Sauás (2), Minas Gerais state, Brazil.

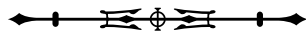


Table 1. List of studied areas in the municipality of Alto Jequitibá, Minas Gerais state, specifying the collecting data, trap type and total effort per area.

\begin{tabular}{c|c|c|c}
\hline Study area & Collecting dates & Trap types & Total effort \\
\hline $\begin{array}{c}\text { RPPN Santuário Ecológico } \\
\text { Mata dos Jacus }\end{array}$ & $\begin{array}{c}\text { November 14-18, 2013 } \\
\text { January 28 to February 01, March 13-17, May 14-18, } \\
\text { August 05-09, October 18-22, 2014 }\end{array}$ & $\begin{array}{c}\text { 40 Sherman } \\
\text { 40 Tomahawk } \\
11 \text { pitfalls }\end{array}$ & 2,730 trap.nights \\
\hline \multirow{3}{*}{ RPPN Refúgio dos Sauás } & $\begin{array}{c}\text { November 14-18, 2013 } \\
\text { January 28 to February 01, March 13-17, May 14-18, } \\
\text { August 05-09, October 18-22, 2014 }\end{array}$ & $\begin{array}{c}\text { 40 Sherman } \\
\text { 40 Tomahawk }\end{array}$ & 2,730 trap.nights \\
\hline Total & 30 days & 182 traps & 5,460 trap.nights \\
\hline
\end{tabular}

To confirm species identifications, specimens were karyotyped in the field using Andrade \& Bonvicino's (2003) methodology. In addition, we identified the specimens based on morphologic characters (Gardner, 2008 [2007]; Patton et al., 2015), and they were deposited in the mammal collection of the Museu de Zoologia Newton Baião de Azevedo (MZNB), Carangola, Minas Gerais State, Brazil. In order of associate species and karyotypes, the skull of one specimen of each species was photographed and composed together the respective species karyotype, except for Thaptomys nigrita. All specimens collected alive were karyotyped.

Chromosome preparations were obtained from short bone marrow cultures in RPMI 1640 medium supplemented with 20\% fetal calf serum and colchicine (10-6 M) for two hours (Andrade et al., 2004). Chromosomes were ordered according to morphology and size. Conventional staining was performed with $5 \%$ Giemsa solution (phosphate buffer, $\mathrm{pH}$ 6.8) and G-banding patterns were carried out according to Seabright (1971). For each cell suspension sample, several metaphases were captured and subjected to microscopic analysis, and five metaphases were mounted. Fundamental number ( $\mathrm{FNa}$ ) refers only to autosome complement. An extensive inventory was carried out in several scientific data bases available online, such as Google Scholar (s. d.) and Web of Science (s. d.) for identifying the localities of karyotyped individuals for each analyzed species. Geographical distributions of each analyzed species were based on Patton et al. (2015) for rodent species and on Gardner (2008 [2007]) for Didelphimorphia species.

\section{RESULTS}

We karyotyped 14 species, 11 rodents and three marsupials (Figures 2 to 6), as bellow described.

Order Rodentia: Abrawayaomys ruschii Cunha \& Cruz, 1979 male MZNB 167 and female MZNB 176, showed $2 \mathrm{n}=58$ and $\mathrm{FNa}=58$ (Figure 2). The autosome complement showed 28 chromosome pairs, one small metacentric and 27 acrocentric pairs varying in size from large to small. The sexual $X$ chromosome is the largest acrocentric chromosome of the complement, and the $Y$ a median size acrocentric. The G-band karyotype was also obtained (Figure 2, bottom left). The autosome complement showed 20 chromosome pairs, 15 acrocentric pairs varying in size from medium to small, and five large biarmed pairs; the sexual $X$ chromosome is a median sized acrocentric and $Y$ a small acrocentric.

Akodon cursor (Winge, 1887), seven males and four females, showed $2 n=14$ (Figure $3 A$ ) with different fundamental autosomal numbers, $F N a=18$ in MZNB 209, MZNB 192, MZNB 234, MZNB 245, FNa $=19$ in MZNB 184, MZNB 232, MZNB 256, $F N a=20$ in MZNB 256, MZNB 208, MZNB 248, and FNa $=21$ in MZNB 164 (Figure $3 \mathrm{~A}$ ), with a small acrocentric $X$ chromosome and a very small $Y$ chromosome. Polymorphisms in fundamental numbers are due to pericentric inversions in the second, third and fourth pairs. Blarinomys breviceps (Winge, 1887)

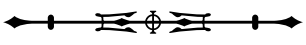




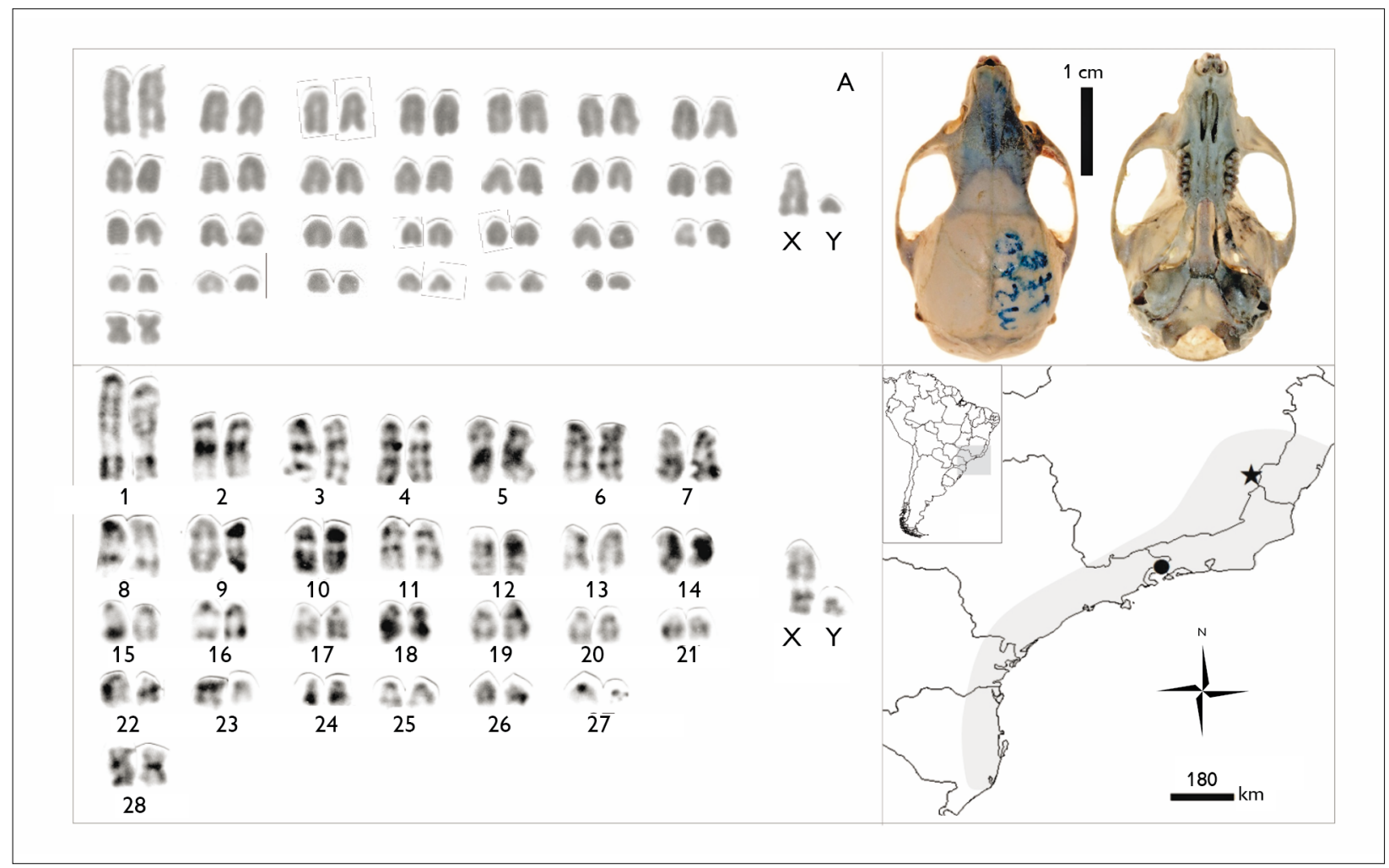

Figure 2. Abrawayaomys ruschii male MZNB 167. Giemsa staining (top lef) and G-banding karyotypes with $2 \mathrm{n}=58$ and FNa $=58$ (bottom left), dorsal and ventral views of the skull (top right), and map of species distribution in gray (according to Patton et al., 2015), with locality of this study (black star), and localities of karyotyped specimens (black circle, for localities list see Table 2) (bottom right).

male MZNB 268 showed $2 n=42$ and $\mathrm{FNa}=50$ (Figure 3B). The autosome complement showed 20 autosomes pairs, five large sized biarmed pairs and 15 acrocentric pairs varying in size from median to small. The $X$ chromosome is a median sized acrocentric and the $Y$ chromosome a small acrocentric (Figure 3B). Oxymycterus dasytrichus (Schinz, 1821), two males (MZNB 171 and MZNB 279), showed 2n $=54$ and $\mathrm{FN}=64$ (Figure 3C), with submetacentric $\mathrm{X}$ and $\mathrm{Y}$ chromosomes. Thaptomys nigrita (Lichtenstein, 1829) female MZNB 275 showed $2 n=52$ and $F N=52$ (Figure 3C). In this species the acrocentric chromosomes are very similar in size to sexual pair (Colombi, 2013; Ventura et al., 2004). So, since we used only Giemsa staining for the karyotype analysis of this sample, we not indicated the sexual pair.

Seven Oligoryzomys nigripes (Olfers, 1818) specimens (MZNB 173, MZNB 175, MZNB 179, MZNB 206,
MZNB 253, MZNB 255, and MZNB 258) showed 2n $=62$ and $\mathrm{FNa}=80-82$ (Figure 4A), with a large sized submetacentric $X$ chromosome and a small acrocentric $Y$. In four specimens, the third and fourth metacentric pairs were heteromorphic, with one biarmed and one acrocentric chromosome. Oligoryzomys flavescens (Waterhouse, 1837) female MZNB 183 showed $2 \mathrm{n}=64$ and $\mathrm{FNa}=66$ (Figure $4 B$ ), with a median size submetacentric $X$ chromosome. Sooretamys angouya (G. Fischer 1814), males MZNB 197 and MZNB 201, showed $2 n=58$ and $F N a=60$ (Figure $4 \mathrm{C}$ ), with a large acrocentric $X$ chromosome and an acrocentric $Y$ chromosome. Rhipidomys tribei Costa, Geise, Pereira \& Costa, 2011 male MZNB 169 showed $2 n=44$ and $\mathrm{FNa}=50$ (Figure 4D), with a medium sized acrocentric $X$ chromosome and a small acrocentric Y chromosome. 
Table 2. List of species found in the study area with karyotypic data, including diploid ( $2 \mathrm{n}$ ) and fundamental autosomal number (FNa), locality, and source. Number between parentheses after locality name refers to the number of specimens herein karyotyped. Legends: Brazilian federative unities - BA (Bahia), CE (Ceará), DF (Federal District), ES (Espírito Santo), GO (Goiás), MG (Minas Gerais), MS (Mato Grosso do Sul), PR (Paraná), RJ (Rio de Janeiro), RS (Rio Grande do Sul), SC (Santa Catarina), SP (São Paulo). Source: $1=$ Sbalqueiro \& Nascimento (1996); 2 = Geise (1995); 3 = Geise et al. (1998); $4=$ Moreira et al. (2009); 5 = Yonenaga (1972); 6 = Paresque et al. (2004); 7 = Yonenaga et al. (1975); 8 = Yonenaga-Yassuda (1979); 9 = Yonenaga-Yassuda et al. (1983); 10 = Fagundes et al. (1998); $11=$ Araújo (2014); 12 = Mochi (2014); 13 = Geise et al. (2004); 14 = Delciellos et al. (2012); 15 = Ventura et al. (2012); $16=$ Zanchin et al. (1992b); 17 = Gonçalves \& Oliveira (2014); 18 = Costa, L. et al. (2007); 19 = Grazzini et al. (2015); 20 = Aguieiras et al. (2013); $21=$ Paresque et al. (2009); 22 = Sbalqueiro et al. (1991); 23 = Pereira, N. et al. (2008); 24 = Di-Nizo et al. (2015); 25 = Di-Nizo et al. (2014); 26 = Almeida \& Yonenaga-Yassuda (1991); 27 = Azevedo (2009); 28 = Almeida Vieira (2012); 29 = Andrades-Miranda et al. (2000); 30 = Araújo Soares (2014); 31 = Bonvicino et al. (2002); 32 = Bonvicino et al. (2014); 33 = Bonvicino et al. (2001a); 34 = Brum-Zorrilla et al. (1988); 35 = Bueno et al. (1987); 36 = Espinosa \& Reig (1991); 37 = Gatto de Almeida (2015); 38 = Grazzini (2014); 39 = Myers \& Carleton (1981); 40 = Svartman (1989); 41 = Tortato et al. (2014); 42 = Weksler \& Bonvicino (2005); 43 = Zanchin (1988); $44=$ Carvalho, A. (2017); 45 = Ventura et al. (2010); 46 = Colombi (2013); $47=$ Moreira \& Oliveira (2011); $48=$ Pereira, N. et al. (2008); 49 = Hass et al. (2011); 50 = Carvalho, B. et al. (2002); 51 = Faria (2008); 52 = Pereira, L. \& Geise (2007).

(Continue)

\begin{tabular}{|c|c|c|c|c|}
\hline Taxa & $2 n$ & $\mathrm{FNa}$ & Locality & Source \\
\hline \multicolumn{5}{|l|}{ Order Rodentia } \\
\hline Abrawayaomys ruschii & 58 & 58 & MG: Alto Jequitibá ( $\mathrm{n}=2)$ & This study \\
\hline Abrawayaomys ruschii & 58 & - & RJ: Angra dos Reis & 23 \\
\hline Akodon cursor & 14 & $18-21$ & MG: Alto Jequitibá $(n=13)$ & This study \\
\hline Akodon cursor & 14 & 18 & $\begin{array}{c}\text { PR: Guaraqueçaba, RJ: Mendes, Rio Bonito, Angra dos Reis, } \\
\text { Sumidouro, Macaé, Casimiro de Abreu } \\
\text { SP: Ubatuba, Guaratatuba } \\
\text { MG: Simão Pereira, Viçosa, Parque Estadual do Brigadeiro } \\
\text { ES: Santa Teresa, Cariacica }\end{array}$ & $1,2,3,4,5,6$ \\
\hline Akodon cursor & 14 & 19 & $\begin{array}{c}\text { RJ: Rio de Janeiro, Pirai, Maricá, Rio Bonito, Rio das Ostras, } \\
\text { Resende, Penedo Maromba } \\
\text { SP: São Paulo, Picinguaba, Salesópolis, Juquitiba, Sete Barras, } \\
\text { Iporanga, Iguapé, Ariri, Ilha do Cardoso, Guatatuba } \\
\text { PR: Guaraqueçaba } \\
\text { MG: Conceição do Mato Dentro, Rio Pomba } \\
\text { ES: Cariacica, Santa Teresa } \\
\text { PR: Matinhos, Paranaguá }\end{array}$ & $\begin{array}{c}1,3,5,6,7,8,9,10 \\
11,12,13\end{array}$ \\
\hline Akodon cursor & 14 & 20 & $\begin{array}{c}\text { RJ: Rio de Janeiro, Nova Friburgo, Resende, Penedo, Maromba } \\
\text { PR: Guaraqueçaba } \\
\text { SP: Iguapé, São Paulo, Sete Barras, Ilha do Cardoso, } \\
\text { Picinguaba, Salesópolis Juquitiba, Guatatuba } \\
\text { BA: Una } \\
\text { ES: Santa Teresa, Cariacica }\end{array}$ & $\begin{array}{c}1,2,3,5,6,7,9,10 \\
11,13,14\end{array}$ \\
\hline Akodon cursor & 14 & 21 & $\begin{array}{c}\text { SP: Iguapé, São Paulo, Picinguaba } \\
\text { RJ: Mendes, Rio de Janeiro } \\
\text { BA: Una } \\
\text { PR: Guaraqueçaba }\end{array}$ & $1,2,3,7,10,11$ \\
\hline Blarinomys breviceps & 43 & 50 & MG: Alto Jequitibá $(n=1)$ & This study \\
\hline Blarinomys breviceps & 43 & 50 & SP: Parque Estadual da Serra da Cantareira & 15 \\
\hline Delomys sublineatus & 72 & 90 & MG: Alto Jequitibá $(n=5)$ & This study \\
\hline Delomys sublineatus & 72 & 90 & $\begin{array}{c}\text { PR: Antonina } \\
\text { ES: Fazenda Monte Verde } \\
\text { MG: Parque Estadual Serra do Brigadeiro } \\
\text { SP: Salesópolis, Caucaia do Alto }\end{array}$ & 16,17 \\
\hline
\end{tabular}

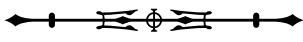


Table 2

\begin{tabular}{|c|c|c|c|c|}
\hline Taxa & $2 n$ & $\mathrm{FNa}$ & Locality & Source \\
\hline Juliomys ossitenuis & 20 & 36 & MG: Alto Jequitibá $(n=1)$ & This study \\
\hline Juliomys ossitenuis & 20 & 36 & $\begin{array}{c}\text { MG: Fervedouro, Dores do Rio Preto } \\
\text { SP: Bananal, Cotia, Piedade, Tapiraí, Ribeirão Grande } \\
\text { PR: Pirai do Sul } \\
\text { RJ: Teresópolis }\end{array}$ & $18,19,20,21$ \\
\hline Oligoryzomys flavescens & 64 & 66 & MG: Alto Jequitibá $(n=1)$ & This study \\
\hline Oligoryzomys flavescens & 64 & 66 & $\begin{array}{c}\text { RS: Mostardas, Osório, Sapiranga Tramandaí, Taim, } \\
\text { Alpestre, Rio dos índios, Erechim Horto Florestal, } \\
\text { Passo Fundo, Chapecó } \\
\text { PR: Ponta Grossa, Curitiba, Piraguara, Esmeralda, } \\
\text { Torres, Curitiba } \\
\text { SP: Iporó }\end{array}$ & $12,22,24$ \\
\hline Oligoryzomys nigripes & 62 & $80-82$ & MG: Alto Jequitibá $(n=9)$ & This study \\
\hline Oligoryzomys nigripes & 62 & $78-82$ & $\begin{array}{c}\text { DF: Brasília } \\
\text { BA: Morro do Chapéu, Rio de uma } \\
\text { CE: Pacoti } \\
\text { ES: Cariacica, Estação Ecológica Santa Lúcia, Monte Verde, } \\
\text { Santa Maria de Jetibá, Santa Teresa, Venda Nova dos Imigrantes } \\
\text { GO: Caldas Novas, Corumbaíba, Ipameri } \\
\text { MG: Alto Caparaó, Caxambu, Juramento, Peirópolis, Serra da } \\
\text { Canastra, Parque Estadual da Serra Brigadeiro } \\
\text { MS: Bodoquena } \\
\text { PR: Iguaçu, FLONA de Piraí do Sul } \\
\text { RJ: Itaguaí, Itatiaia, Nova Friburgo, Rio Claro, Sumidouro, } \\
\text { Teresópolis } \\
\text { RS: Alpestre, Aratiba, Caxias do Sul, Chapecó, Charqueadas, } \\
\text { Erechim, Ivaí, PE do Turvo, Derrubadas, Estação Ecológica } \\
\text { do Taim, Maquiné, Mostardas, Morro Alto, Muitos Capões, } \\
\text { Osório, Picada Verão, Quintão, Reserva Biológica Estadual do } \\
\text { Sassafrás, Riozinho, Rio dos Îndios, São Francisco de Paula, } \\
\text { Sapiranga, Tainhas, Tapes, Torres, Tramandaí, Tupanciretã } \\
\text { SC: Concordia, Costa de entro, Ilha de Santa Catarina, São } \\
\text { Francisco do Sul } \\
\text { SP: Águas de Santa Bárbara, Araçariguama, Araraquara, Casa } \\
\text { Grande, Guaratuba, Iguapé, Iporanga, Itapetininga, Intervales, } \\
\text { Juquá,, Luiz Antônio, Pedreiras Pedro de Toledo, Parque } \\
\text { Estadual Serra do Mar, Pilar do Sul, Santa Maria da Serra, } \\
\text { Ribeirão Preto, Rio Claro, Santa Virgínia, Santo Antônio, } \\
\text { Taubaté }\end{array}$ & $\begin{array}{l}4,6,13,12,21,24 \\
25,26,28,29,30 \\
31,32,33 a, 34 \\
35,36,37,38,39 \\
40,41,42,43\end{array}$ \\
\hline Oxymycterus dasytrichus & 54 & 64 & MG: Alto Jequitibá $(n=1)$ & This study \\
\hline Oxymycterus dasytrichus & 54 & 64 & $\begin{array}{c}\text { MG: Parque Estadual do Brigadeiro } \\
\text { RJ: Itatiaia } \\
\text { PR: Matinhas }\end{array}$ & $4,12,13$ \\
\hline Rhipidomys tribei & 44 & 50 & MG: Alto Jequitibá $(n=1)$ & This study \\
\hline Rhipidomys tribei & 44 & 50 & $\begin{array}{l}\text { ES: Castelo, Ibitirana, Muqui } \\
\text { MG: Fervedouro, Santa Barbara }\end{array}$ & 44 \\
\hline Sooretamys angouya & 58 & 60 & MG: Alto Jequitibá & This study \\
\hline
\end{tabular}

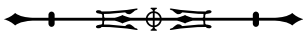


Table 2.

(Conclusion)

\begin{tabular}{|c|c|c|c|c|}
\hline Taxa & $2 n$ & $\mathrm{FNa}$ & Locality & Source \\
\hline Sooretamys angouya & 58 & 60 & $\begin{array}{c}\text { ES: Monte Verde } \\
\text { RS: Sapiranga, Tramandaí, Mostardas, Faxinal, Torres, } \\
\text { Tramandaí, Caxias do Sul, Quintão, Osorio, Doutor Pedrito } \\
\text { SC: Florianópolis } \\
\text { PR: Piraí do Sul } \\
\text { MG: Parque Nacional do Caparaó } \\
\text { SP: Santa Virgínia, Parque Estadual da Serra do Mar }\end{array}$ & $20,25,32,38,41$ \\
\hline Thaptomys nigrita & 52 & 52 & $\begin{array}{c}\text { MG: Fervedouro. ES: Santa Teresa, Domingos Martins, } \\
\text { Dores do Rio Preto, Luminárias. SP: São Bernardo do Campo, } \\
\text { Biritiba Mirim, Pilar Do Sul, Iguapé, São João Batista da } \\
\text { Boa Vista, Ibiúna, Piedade, Tapirai, Cotia, Capão Bonito, } \\
\text { Piraquara, Santa Virginia } \\
\text { PR: Ortigueira, Matinhos, Piraguara, Curitiba } \\
\text { RS: Maniqué } \\
\text { SC: Blumenau } \\
\text { BA: Una }\end{array}$ & $\begin{array}{c}4,6,31,37,45,46 \\
47,49\end{array}$ \\
\hline Thaptomys nigrita & 52 & 52 & MG: Alto Jequitibá $(n=1)$ & This study \\
\hline \multicolumn{5}{|c|}{ Order Didelphimorphia } \\
\hline Monodelphis scalops & 18 & & MG: Alto Jequitibá $(n=2)$ & This study \\
\hline Monodelphis scalops & 18 & 30 & SP: Santa Virginia & 12 \\
\hline Marmosops incanus & 14 & 24 & MG: Alto Jequitibá $(n=14)$ & This study \\
\hline Marmosops incanus & 14 & 24 & $\begin{array}{c}\text { BA: Pau-Brasil, Lençóis, Remanso } \\
\text { MG: Santa Barbara, Pedra Dourada, Fervedouro, Tombos } \\
\text { ES: Santa Teresa, Cariacica } \\
\text { SP: Caucaia do Alto, Parque Estadual da Serra do Mar, } \\
\text { Santa Virginia }\end{array}$ & $6,25,27,50,51,52$ \\
\hline Philander quica & 22 & & MG: Alto Jequitibá $(n=4)$ & This study \\
\hline Philander quica & 22 & 20 & $\begin{array}{c}\text { RJ: Angra dos Reis } \\
\text { SP: Santa Virginia, Serra da Cantareira } \\
\text { SC: Doutor Pedrito } \\
\text { RS: Aratinga, Sapiranga, Osório } \\
\text { ES: Santa Teresa }\end{array}$ & $6,25,38,48,50$ \\
\hline
\end{tabular}

Two specimens of Delomys sublineatus (Thomas, 1903) were collected, the female MZNB 243 and the male MZNB 216 that showed $2 n=72$ and $F N a=90$ (Figure $5 A$ ), with a large sized submetacentric $X$ chromosome and a small acrocentric $Y$ chromosome. Juliomys ossitenuis Costa, Pavan, Leite \& Fagundes, 2007, male MZNB 207, showed 2n= 20 and $\mathrm{FNa}=36$ (Figure 5B), with a large metacentric $\mathrm{X}$ chromosome and a medium submetacentric $Y$ chromosome.

Order Didelphimoprhia: two Monodelphis scalops (Thomas, 1888) were collected, male MZNB
269, and male MZNB 180 that showed $2 \mathrm{n}=18$ (Figure 6A), with small acrocentric $X$ and $Y$ sexual chromosomes. Two Philander quica (Temminck, 1824) were collected, male MZNB 239, and male MZNB 165 that showed $2 n=22$ (Figure 6B), with a medium acrocentric $X$ chromosome and a small acrocentric $Y$ chromosome. Marmosops incanus (Lund, 1840) male MZNB 241 showed $2 n=14$ (Figure 6C), with a medium submetacentric $X$ chromosome and a small $Y$ chromosome. 


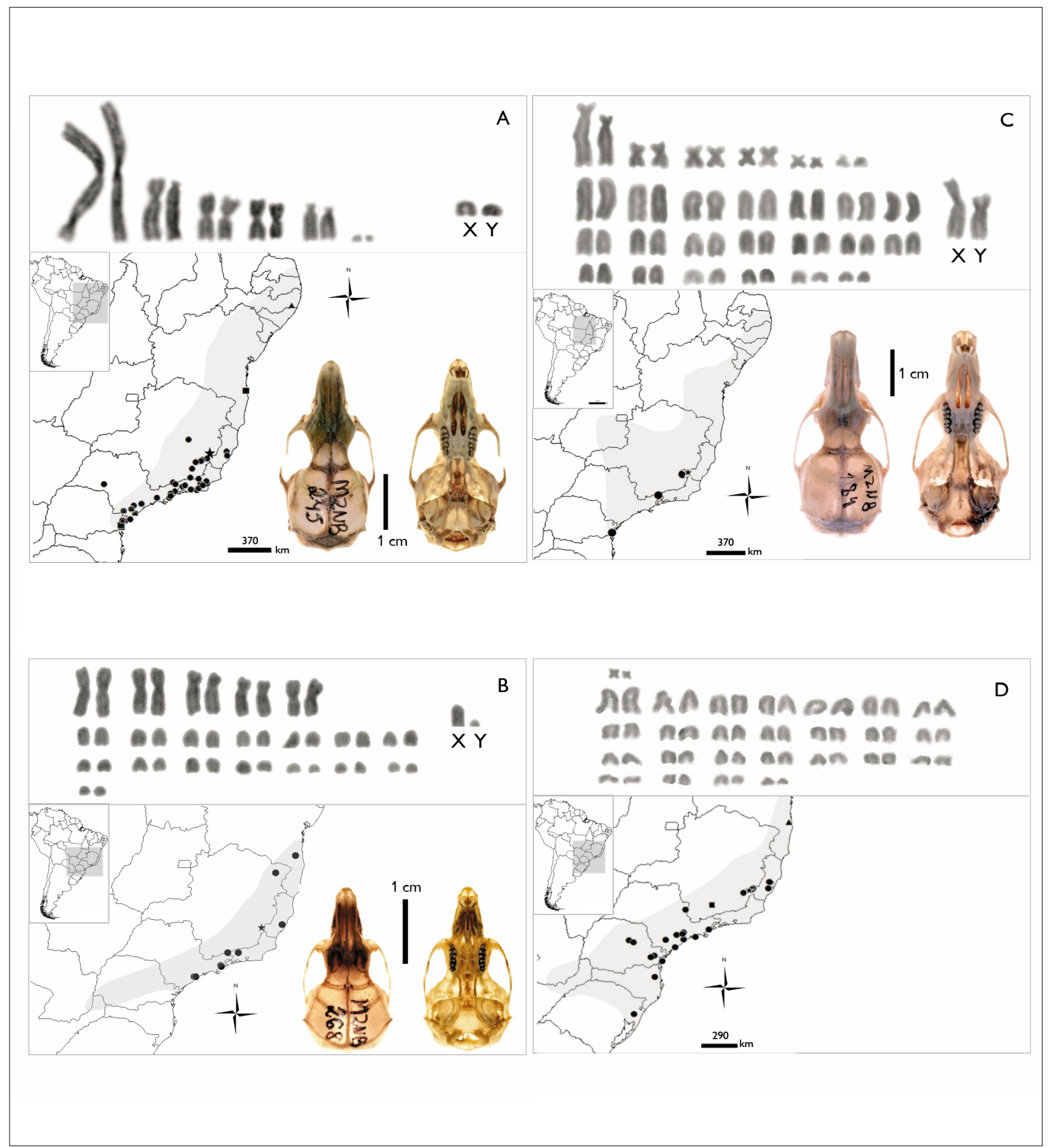

Figure 3. Giemsa staining karyotypes, maps of species distribution in gray (according to Patton et al., 2015), with study area (black star) and localities of karyotyped specimens from previous studies (black circle; for localities and sources see Table 2), and ventral and dorsal skull views of: A) Akodon cursor male MZNB 164 with $2 n=14$ and $F N a=21$; B) Blarinomys breviceps male MZNB 268 with $2 n=42$ and $\mathrm{FNa}=50$; C) Oxymycterus dasytrichus male MZNB 171 with $2 \mathrm{n}=54$ and $\mathrm{FNa}=64$; D) Thaptomys nigrita female MZNB 275 with $2 \mathrm{n}=52$ and $\mathrm{FNa}=52$ (with no indication of sexual pair, and with no figured skull). Black square = locality with different karyotype from the specimens of the study area. 

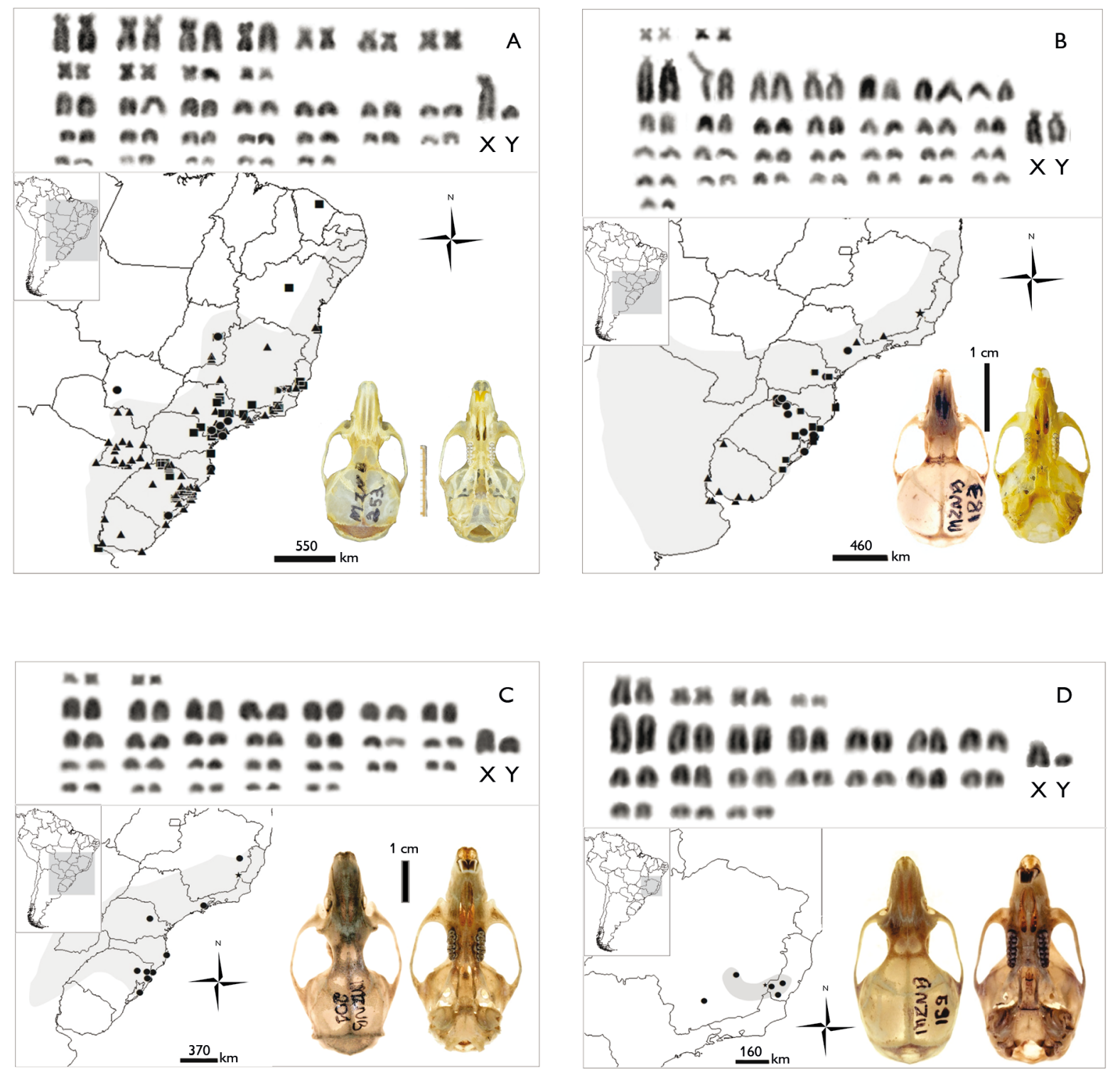

Figure 4. Giemsa staining karyotypes, maps of species distribution in gray (according to Patton et al., 2015), with the study area (black star) and localities of karyotyped specimens from previous studies (black circle; for localities and sources see Table 2), and ventral and dorsal skull views of: A) Oligoryzomys nigripes male MZNB 179 with $2 n=62$ and FNa $=80$ (skull MZNB 253); B) Oligoryzomys flavescens, MZNB 183, $2 \mathrm{n}=64$ and FNa =66; C) Sooretamys angouya male MZNB 197 with $2 \mathrm{n}=58$ and FNa = 60 (skull MZNB 201); D) Rhipidomys tribei male MZNB 169 with $2 n=44$ and $\mathrm{FNa}=50$. Black square = locality with different karyotype from the specimens of the study area. Black triangles $=$ localities with the same and different karyotypes.

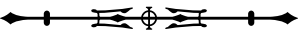




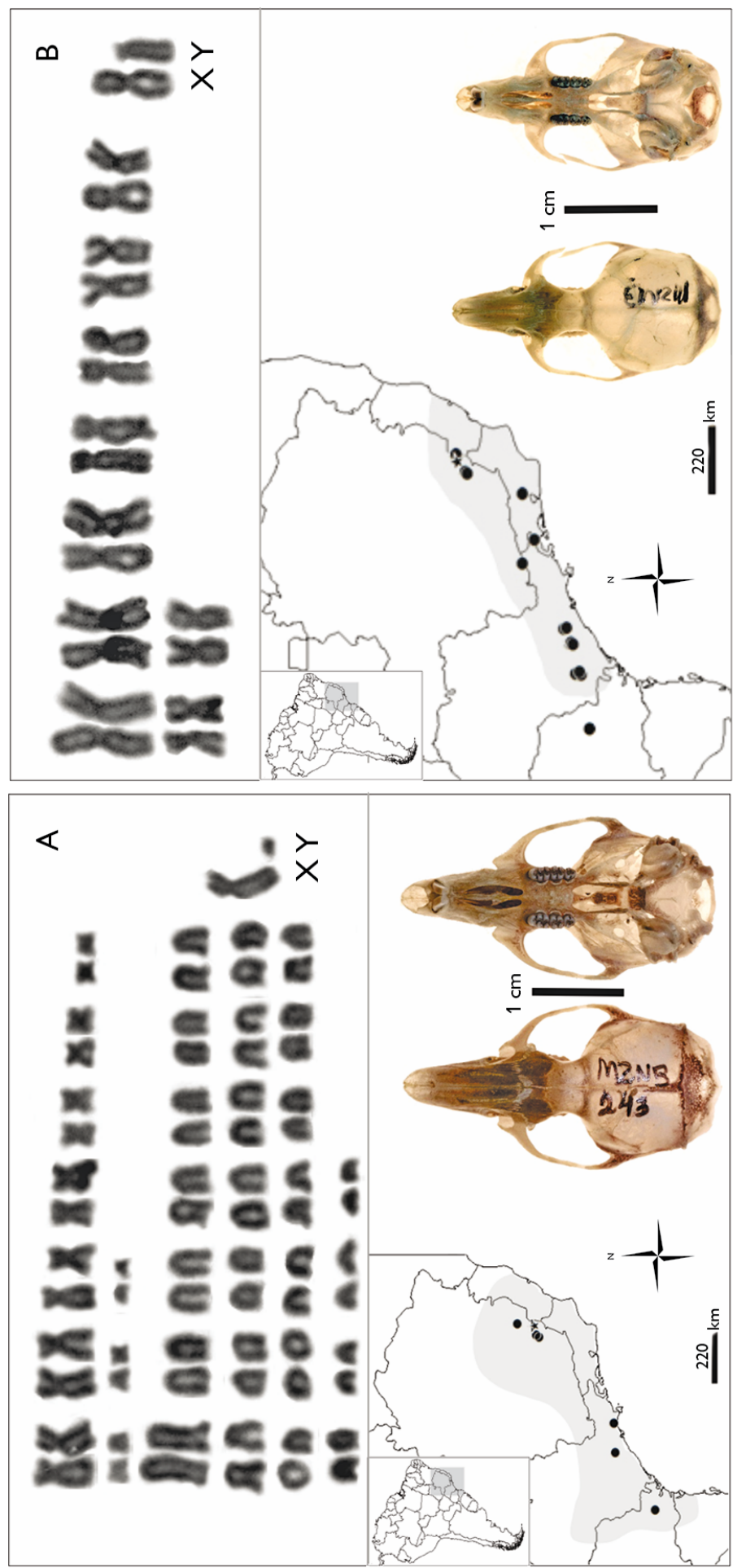

ᄃ요용

皮

bo

ठํ 


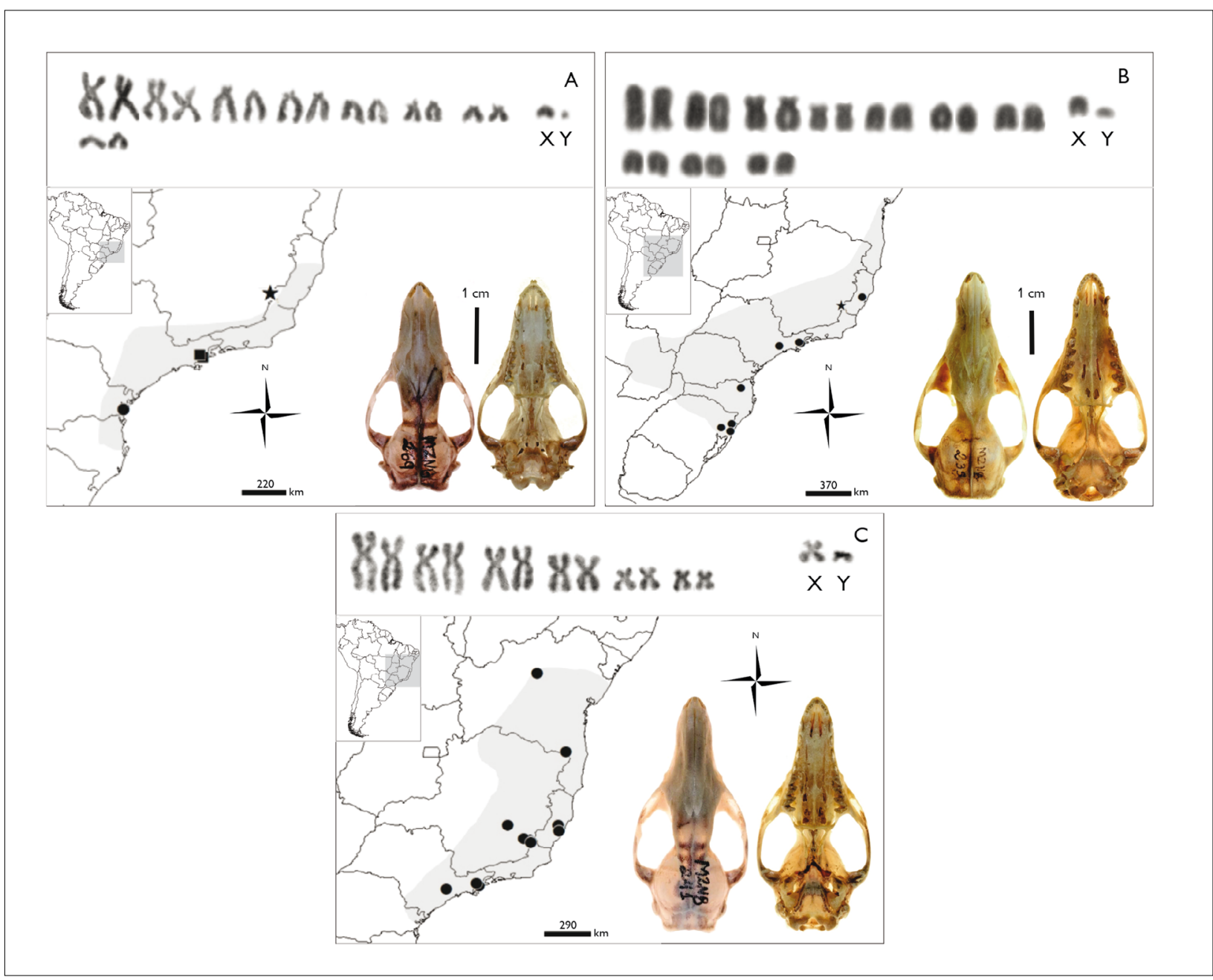

Figure 6. Giemsa staining karyotypes, maps of species distribution (modified from Pine \& Handley Jr., 2008 [2007]) in gray, with the study area (black star), and localities of karyotyped specimens from previous studies (black circle; for localities and sources see Table 2), and ventral and skulls dorsal views of: A) Monodelphis scalops male MZNB 180 with $2 n=18$ and FNa $=20$, and skull of male MZNB 269, B) Philander quica male MNZB 165 (MBF145) with $2 n=22$ and FNa $=20$, and skull of male MZNB 239, C) Marmosops incanus male MZNB 241 with $2 n=14$ and $F N a=24$.

\section{DISCUSSION}

The karyotype herein reported for Abrawayaomys ruschii with $2 n=58$, is similar to the single one previously reported for a specimen from Rio de Janeiro state (Pereira,

L. et al., 2008). However, the autosomal fundamental number and the sexual chromosomes cannot be identified by Pereira, L. et al. (2008) due to the poor quality of the preparation. Herein the acrocentric $X$ and $Y$ sexual chromosomes, and the $\mathrm{FNa}$ of 60 is described for the first time. After G-banding, all chromosome pairs of this species could be identified (Figure 2). Abrawayaomys ruschii is a poor known species and is considered as incertae saedis (Ventura et al., 2013), whereas a recent study suggested its close relationship with the tribe Akodontini (Gonçalves et al., 2020). Some authors suggested the presence of a third and undescribed species of Minas Gerais Abrawayaomys (Pardiñas et al., 2009), however our data showed that in the localities sampled in Minas Gerais the species

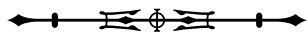


present is Abrawayaomys ruschii. The geographical distance (378 km) between the two areas where the karyologic studies have been published, one in the state of Rio de Janeiro and another in Minas Gerais state, suggest a conserved chromosome complement for $A$. ruschii.

Blarinomys breviceps' new karyotype herein described, with $2 \mathrm{n}=42$ and $\mathrm{FNa}=50$, differs from all others described for this species. Eight distinct karyomorphs have already been described for this monospecific genus with a variation in diploid numbers $(2 n)$ due to arrangements involving autosomes and the presence of $b$ chromosomes (B): $2 n=52,2 n=50+2 B, 2 n=44+1 B, 2 n=39$ $+4 \mathrm{Bs}, 2 \mathrm{n}=36+1,2 \mathrm{n}=34,2 \mathrm{n}=29+2 \mathrm{Bs}, 2 \mathrm{n}=$ 28 (Geise et al., 2008; Ventura et al., 2012). The map in Figure 3 shows localities with cytogenetic studies. All these karyotypes, including the one herein described, share the same fundamental autosomal number of 50 and the $X Y$ sexual system, with a variation in diploid numbers due to up 4 supernumerary chromosomes and Robertsonian arrangement (Ventura et al., 2012). Blarinomys is considered a fossorial rodent due to its adaptations to fossorial living (Teta \& Pardiñas, 2015). Fossorial rodents often have a high level of intra and inter-specific polymorphism (Ipucha et al., 2008). The presence of two evolutive lineages of Blarinomys breviceps in the Atlantic Forest suggested by phylogenetic analysis (Ventura et al., 2012), indicate that further studies are necessary for understanding whether the karyologic variation of this taxon is polymorphism.

The tribe Akodontini included several genera that occur in Brazil (Patton et al., 2015), and we analyzed karyotypes of specimens belonging to four genera of this tribe, Akodon, Blarinomys, Oxymycterus, and Thaptomys. Akodon cursor karyotypes herein found were within the variation described for this species (Table 2). Polymorphism due to pericentric inversion and centric fusion/fission in the largest chromosome of the complement is well documented, with karyotypes ranging from $2 \mathrm{n}=14$ to 16 and $\mathrm{FNa}=18$ to 26 (Yonenaga, 1975; Yonenaga-Yassuda et al., 1983; Maia \& Langguth, 1981; Kasahara \& Yonenaga-Yassuda, 1984;
Fagundes et al., 1998; Geise et al., 1998; Sbalqueiro \& Nascimento, 1996; Ventura et al., 2004; Pereira, L. \& Geise, 2007; Moreira et al., 2009). The $2 n=16$ is fixed in the extreme north of the species distribution (Maia \& Langguth, 1981) with a single record in the extreme south of distribution in Guaraqueçaba, Paraná state, where all three diploid numbers were found (Sbalqueiro \& Nascimento, 1996). Despite this polymorphism, the karyotype of Akodon cursor is easily identified, and specimens were karyotyped throughout its distribution (Figure 3A).

Oxymycterus dasytrichus karyotype with $2 n=54$ and $\mathrm{FNa}=62$ herein reported is similar to those already described for this species in Minas Gerais and Paraná states (Moreira et al., 2009; Mochi, 2014; Figure 3C). Despite variations in external and cranial morphology, all species of this genus share the same 2n and FNa (Mattevi et al., 1982; Sbalqueiro et al., 1982; Hershkovitz, 1998; Bonvicino, 2011), and this constancy leads to few karyologic studies carried out with Oxymycterus species.

Thaptomys nigrita karyotype showed $2 \mathrm{n}=52$ and $\mathrm{FNa}=52$ (Figure 3D), similar to those reported to specimens from Rio Grande do Sul, Paraná, São Paulo, Rio de Janeiro, Espírito Santo, and Minas Gerais states (Yonenaga et al., 1975; Paresque et al., 2004; Ventura et al., 2004, 2010; Moreira et al., 2009; Delciellos et al., 2012). Two other karyotypes were attributed to $T$. nigrita, one with $2 \mathrm{n}=48-51$ and $\mathrm{FNa}=52$ described for specimens from Luminárias in Minas Gerais state (Colombi, 2013), and another with $2 \mathrm{n}=50$ and $\mathrm{FNa}=48$ for specimens from Una, Bahia state (Ventura et al., 2004).

The tribe Oryzomyini included several genera that occur in Brazil, and we analyzed karyotypes of specimens belonging to the two genera of this tribe, Oligoryzomys and Sooretamys (Patton et al., 2015). The $2 n=62$ is constant in 0 . nigripes, with variations in fundamental autosomal numbers from 78 to $80-82$ due to pericentric inversion affecting up to four autosome pairs (pairs 2, 3, 4, 8) throughout its distribution, in Brazil (Yonenaga et al., 1976; Bueno et al., 1987; Zanchin, 1988; Almeida \& Yonenaga-Yassuda, 1991;

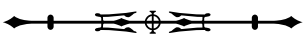


Bonvicino \& Weksler, 1998; Andrades-Miranda et al., 2000; Bonvicino et al., 2001a), Paraguay (Myers \& Carleton, 1981), and Argentina (Espinosa \& Reig, 1991). Despite variations in fundamental autosomal numbers due to pericentric inversions (Almeida \& Yonenaga-Yassuda, 1991; Andrades-Miranda et al., 2000; Figure 4A), and polymorphism in the morphology of $X$ chromosome (Paresque et al., 2007), O. nigripes can easily be identified by its chromosome complement. The karyotype data in the literature increased $O$. nigripes' geographic distribution west up to Morro do Chapéu in Bahia state, Pacoti in Ceará state, and Bodoquena in Mato Grosso do Sul state (Paresque et al., 2007; Figure 4A), showing the importance of karyologic data in the identification and delimitation of species distribution boundaries.

The Sooretamys angouya karyotype with $2 \mathrm{n}=58$ and $\mathrm{FN}=60$ is similar to the one found in other localities throughout the Atlantic Forest (Andrades-Miranda et al., 2000; Silva \& Yonenaga-Yassuda, 2004; Di-Nizo et al., 2014). Polymorphism in diploid numbers (57-58) due to a Robertsonian rearrangement involving autosomes has already been reported in specimens identified as Oryzomys ratticeps (Kasahara \& Yonenaga-Yassuda, 1984), as well as the presence of up to two supernumerary chromosomes, resulting in $2 n=60$ (Silva \& Yonenaga-Yassuda, 2004). The chromosome complement of $S$. angouya was known only in part of its distribution (Figure 4B), with no karyotype description available for its distribution in the west.

We karyotyped specimens belonging to one genus of the tribe Thomasomyini, Rhipidomys (Patton et al., 2015). The karyotype of Rhipidomys tribei, $2 \mathrm{n}=44$ and $\mathrm{FNa}=50$ (Figure 4D) has already been reported for specimens from Espírito Santo and Minas Gerais states (Zanchin et al., 1992a; Costa, B. et al., 2011; Carvalho, A., 2017). Other Rhipidomys species, such as Rhipidomys cariri from Pernambuco and Ceará states (Thomazini, 2009; Carvalho, A., 2017), Rhipidomys Itoan from São Paulo and Rio de Janeiro states (Geise, 1995; Di-Nizo et al., 2014; Carvalho, A., 2017), R. gardneri from Acre state (Patton et al., 2000) and R. macconnelli from Bolivar in Venezuela (Aguilera et al., 1994) share the same
$2 n=44$ and $\mathrm{FNa}=50$. However, these karyotypes differ from each other in their autosome complement morphology and in the presence of constitutive heterochromatin.

Recently the Juliomys genus was considered to belong to the tribe Wiedomyini tribe together with Wiedomys, Phaenomys and Wilfredomys (Gonçalves et al., 2020). The Juliomys ossitenuis karyotype herein reported is similar to the one found in specimens from Minas Gerais, Rio de Janeiro and Paraná states (Aguieiras et al., 2013; Costa, L. et al., 2007; Grazzini et al., 2015). This species showed a conservative karyotype throughout its distribution and a distribution greater than the one reported in the last compilation for the genus (Patton et al., 2015). We karyotype two genera of Sigmodontinae incertae sedis, Abrawayaomys (above discussed) and Delomys. Delomys sublineatus karyotype herein reported is similar to the one found throughout its distribution (Zanchin et al., 1992b; Gonçalves \& Oliveira, 2014).

The Didelphidae species are characterized by a conservative karyotype with only three diploids numbers, 14, 18 and 22 (Reig et al., 1977; Carvalho, B. et al., 2002). This conserved chromosome complement led to few studies with this group (Figure 6). Data herein presented corroborated previous reports about Monodelphis scalops with $2 \mathrm{n}=18$ and $\mathrm{FNa}=30$ (Di-Nizo et al., 2014), Marmosops incanus with $2 \mathrm{n}=14$ and $\mathrm{FNa}=24$ (Carvalho, B. et al., 2002; Faria, 2008) and P. quica with $2 n=22$ and $\mathrm{FNa}=20$ (Pereira, N. et al., 2008; Di-Nizo et al., 2014).

The different karyotype herein found for Blarinomys can be related to the topography of the area. The Serra da Mantiqueira contains the highest inselberg-type landforms in South America, and has a high generic and species-level diversity, probably due to the old age of the Atlantic forest and its flora and fauna (Por, 1992; Porembski \& Barthlott, 2000). The southeastern region of Brazil, where the Zona da Mata and the Atlantic Forest are located, is formed by a topographical complex of mountains, which directly influence this biome's landscapes (Costa, L. et al., 2000) with altitudinal variations of 0 to $2,900 \mathrm{~m}$. The studied area is postulated as a refugium in the Southeast Brazilian

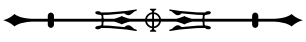


Atlantic Forest (Porto et al., 2012), and the data herein reported, with a high number of little known and, or, endemic species, such as Abrawayaomys ruschii (Pardiñas et al., 2015), Blarinomys breviceps (Teta \& Pardiñas, 2015), and Phyllomys lundi (Leite \& Loss, 2015), is consistent with this hypothesis.

This study confirms the Zona da Mata Mineira as a hotspot region in the Atlantic Forest and showed the importance of karyotype analysis in identifying known and still unknown small mammals, in addition to likely contributing to biogeographic and taxonomic studies of these rodents.

\section{ACKNOWLEDGMENTS}

We are grateful for Sr. Carlos Monteiro and Rita de Cassia for facilities and permission to collect in Fazenda Harmonia (Harmonia farm), where are the RPPNs; to the members of Museu de Zoologia Newton Baião de Azevedo for help in field work; to two anonym reviewers and the editor Alexandra Bezerra for valuables suggestions. This work was supported by grants from Conselho Nacional de Pesquisa e Desenvolvimento (CNPq) (process number 304498/20149) and Fundação de Amparo à Pesquisa do Estado do Rio de Janeiro (FAPERJ) (process number E-26/201.200/2014) to CRB. MB receives fellowship from $\mathrm{CNPq}$ (process number 150387/2014-8), and RL from CAPES and FAPERJ (process number E26/201.812/2019).

\section{REFERENCES}

AB'SABER, A. N., 1977. Espaços ocupados pela expansão dos climas secos na América do Sul por ocasião dos períodos glaciais quaternários. Paleoclimas (3): 1-19.

AGUIEIRAS, M., B. A. SANTOS, L. AZAMOR, J. L. BARBOSA, A. C. BEZERRA, K. C. C. SILVA \& L. GEISE, 2013. Primeiro registro de Juliomys ossitenuis Costa, Pavan, Leite and Fagundes, 2007 e simpatria com/uliomys pictipes (Osgood, 1933) (Rodentia, Cricetidae, Sigmodontinae) na Serra dos Órgãos, Rio de Janeiro. Boletim da Sociedade Brasileira de Mastozoologia 68: 57-64. Available at: https://www.researchgate.net/publication/282266747. Accessed on: September 28, 2020.

AGUILERA, M., A. PÉREZ-ZAPATA, A. MARTINO, M. A. BARROS \& J. PATTON 1994. Karyosystematics of Aepomys and Rhipidomys (Rodentia, Cricetidae). Acta Científica Venezolana 45: 247-248.
ALMEIDA, E. J. C. \& Y. YONENAGA-YASSUDA, 1991. Pericentric inversion and sexual chromosome heteromorphisms in Oryzomys nigripes (Rodentia, Cricetidae). Caryologia 44(1): 63-73. DOI: http:// doi.org/10.1080/00087114.1991.10797020

ALMEIDA, F. F. M. \& C. D. R. CARNEIRO, 1998. Origem e evolução da Serra do Mar. Revista Brasileira de Geociências 28(2): 135-150.

ALMEIDA VIEIRA, P. B., 2012. Diversidade e cariótipo de pequenos mamíferos não-voadores do Parque Estadual Acaraí, São Francisco do Sul. Monograph - Biological Sciences course, Universidade da Região de Joinville, Joinville.

ANDRADE, A. F. B. \& C. R. BONVICINO, 2003. A new karyologic variant of Oecomys (Rodentia: Sigmodontinae) and its phylogenetic relationship based on molecular data. Genome 46(2): 195-203. DOI: http://doi.org/10.1139/g02-123

ANDRADE, A. F. B., C. R. BONVICINO, D. C. BRIANI \& S. KASAHARA, 2004. Karyologic diversification and phylogenetic relationships of the genus Thalpomys (Rodentia, Sigmodontinae). Acta Theriologica 49(2): 181-190. DOI: http://doi.org/10.1007/ BF03192519

ANDRADES-MIRANDA, J., N. I. T. ZANCHIN, L. F. B. OLIVEIRA, A. R. LANGGUTH \& M. S. MATTEVI, 2000. Cytogenetic studies in nine taxa of the genus Oryzomys (Rodentia, Sigmodontinae) from Brazil. Mammalia 65(4): 461-472. DOI: http://doi.org/10.1515/ mamm.2001.65.4.461

ANDRADES-MIRANDA J., L. F. B. OLIVEIRA, C. A. V. LIMAROSA, A. P. NUNES, N. I. T. ZANCHIN \& M. S. MATTEVI, 2001. Chromosome studies of seven species of Oligoryzomys (Rodentia: Sigmodontinae) from Brazil. Journal of Mammalogy 82(4): 10801091. DOI: http://doi.org/10.1644/1545-1542(2001)082<1080:CS $\mathrm{OSSO}>2.0 . \mathrm{CO} ; 2$

ARAÚJO, P. N., 2014. Genômica comparativa dos roedores Akodontinos Akodon cursor, A. montensis e Necromys lasiurus (Cricetidae: Rodentia). Master Thesis - Universidade Federal de Minas Gerais, Belo Horizonte.

ARAÚJO SOARES, A., 2014. Caracterização cariotípica em roedores do Parque Estadual do Acaraí, São Francisco do Sul, Santa Catarina. Monograph - Biological Sciences course, Universidade Federal do Paraná, Curitiba. Available at: https://acervodigital.ufpr.br/ bitstream/handle/1884/40414/MONOGRAFIA\%20AMANDA\%20 DE\%20ARAUJO\%20SOARES. pdf? sequence=1. Accessed on: September 28, 2020.

AZEVEDO, N. F., 2009. Evolução cromossômica em mamíferos: estudos comparativos por pintura cromossômica em duas espécies de preguiças da família Bradypodidae e em duas espécies de marsupiais da família Didelphidae. PhD dissertation - Universidade de São Paulo, São Paulo.

BONVICINO, C. R. \& M. WEKSLER, 1998. A new species of Oligoryzomys (Rodentia, Sigmodontinae) from central Brazil. Zeitschrift für Säugetierkunde 63: 90-103.

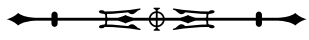


BONVICINO, C. R., P. S. D'ANDREA \& P. BORODIN, $2001 \mathrm{a}$. Pericentric inversions: a study in natural populations of Oligoryzomys nigripes (Rodentia: Sigmodontinae). Genome 44(5): 791-796. DOI: http://doi.org/10.1139/gen-44-5-791

BONVICINO, C. R., J. A. DE OLIVEIRA, P. S. D'ANDREA \& R. W. CARVALHO, 2001b. Rediscovery of the endemic Atlantic Forest rodent Phaenomys ferrugineus (Sigmodontinae): new data on its morphology and karyology. Boletim do Museu Nacional, Nova Série, Zoologia 467: 1-12.

BONVICINO, C. R., S. M. LINDBERGH \& L. S. MAROJA, 2002. Small non-flying mammals from conserved and altered areas of Atlantic forest and Cerrado: comments on their potential use for monitoring environment. Brazilian Journal of Biology 62(4b): 765-774. DOI: http://doi.org/10.1590/S1519-69842002000500005

BONVICINO, C. R., J. F. S. LIMA \& F. C. ALMEIDA, 2003. A new species of Calomys Waterhouse (Rodentia, Sigmodontinae) from the Cerrado of Central Brazil. Revista Brasileira de Zoologia 20(2): 301-307. DOI: https://doi.org/10.1590/S0101-81752003000200021

BONVICINO, C. R., 2011. Diversidade cariotípica em roedores Akodontini do Brasil. Boletim da Sociedade Brasileira de Mastozoologia (62): 7-13.

BONVICINO, C. R., F. A. FERNANDES, M. C. VIANA, B. R. TEIXEIRA \& P. S. D'ANDREA, 2013. Scapteromys aquaticus (Rodentia: Sigmodontinae) in Brazil with comments on karyotype and phylogenetics relationships. Zoologia 30(2): 242-247. DOI: http://doi.org/10.1590/S1984-46702013000200016

BONVICINO, C. R., A. LAZAR, M. M. CORREAA, M. WEKSLER, A. COSTA PAULA \& A. M. BEZERRA, 2014. Conservation units in the core area of the Cerrado domain: an overview on the small nonvolant mammals (Rodentia and Didelphimorphia). Heringeriana 8: $202-221$

BRUM-ZORRILLA, N., T. G. FRONZA, R. WAINBERG, L. VIDALRIOJA \& N. ZWIRNER, 1988. Oryzomys flavescens and O. delticola chromosomes (Rodentia, Cricetidae) from Uruguay and Argentina. Caryologia 41(3-4): 275-288. DOI: http://doi.org/10.1080/00087 114.1988.10797868

BUENO, A. M. S., J. M. S. AGOSTINI, J. MORAES \& A. P. D. RAMOS, 1987. Estudos cromossômicos preliminares de roedores da família Cricetidae coletados na Ilha de Santa Catarina. Ciência e Cultura 39: 346-347.

CARNAVAL, A. C., M. J. HICKERSON, C. F. B. HADDAD, M. T. RODRIGUES \& C. MORITZ, 2009. Stability predicts genetic diversity in the Brazilian Atlantic Forest Hotspot. Science 323(5915): 785-789. DOI: http://doi.org/10.1126/science.1166955

CARNAVAL, A. C. \& C. MORITZ, 2008. Historical climate modelling predicts patters of current biodiversity in the Brazilian Atlantic Forest. Journal of Biogeography 35(7): 1187-1201. DOI: http://doi. org/10.1111/j.1365-2699.2007.01870.x
CARVALHO, A. H., 2017. Evolução molecular e cariotípica em Rhipidomys Tschudi, 1845 (Rodentia, Cricetidae). PhD dissertation - Universidade Federal do Espírito Santo, Vitória.

CARVALHO, B. A., L. F. B. OLIVEIRA, A. P. NUNES \& M. S. MATTEVI, 2002. Karyotypes of nineteen marsupial species from Brazil. Journal of Mammalogy 83(1): 58-70. DOI: http://doi. org/10.1644/1545-1542(2002)083<0058:KONMSF>2.0.CO;2

COLOMBI, V. H., 2013. Thaptomys (Thomas 1916) (Rodentia, Cricetidae): um gênero monotípico? Uma abordagem citogenética e molecular. Master Thesis - Postgraduate Program in Biological Sciences, Universidade Federal do Espírito Santo, Vitória.

COSTA, B. M. A., L. GEISE, L. G. PEREIRA \& L. P. COSTA 2011. Phylogeography of Rhipidomys (Rodentia, Cricetidae: Sigmodontinae) and description of two new species from southeastern Brazil. Journal of Mammalogy 92(5): 945-962. DOI: http://doi.org/10.1644/10-MAMM-A-249.1

COSTA, L. P., Y. L. R. LEITE, G. A. B. FONSECA \& M. T. FONSECA, 2000. Biogeography of South American forest mammals: endemism and diversity in the Atlantic Forest. Biotropica 32(4b): 872-881. DOI: http://doi.org/10.1111/j.1744-7429.2000.tb00625.x

COSTA, L. P., S. E. PAVAN, Y. L. R. LEITE \& V. FAGUNDES, 2007. A new species of Juliomys (Mammalia, Rodentia, Cricetidae) from the Atlantic Forest of southeastern Brazil. Zootaxa 1463: 21-37. DOI: http://doi.org/10.5281/zenodo.176477

DELCIELLOS, A. C., R. L. M. NOVAES, M. F. C. LOGUERCIO, L. GEISE, R. T. SANTORI, R. F. SOUZA, B. S. PAPI, D. S. L. RAÍCES, N. R. VIEIRA, S. FELIX, N. DETOGNE, C. C. S. SILVA, H. G. BERGALLO \& O. ROCHA-BARBOSA, 2012. Mammals of Serra da Bocaina National Park, state of Rio de Janeiro, southeastern Brazil. Check List 8(4): 675-692. DOI: http://doi. org/10.15560/8.4.675

DI-NIZO, C. B., C. L. NEVES, J. F. VILELA \& M. J. J. SILVA, 2014. New karyologycal data and cytotaxonomic considerations on small mammals from Santa Catarina (Parque Estadual da Serra do Mar, Atlantic Forest, Brazil). Comparative Cytogenetics 8(1): 11-30. DOI: http://doi.org/10.3897/CompCytogen.v8i1.6430

DI-NIZO, C. B., K. VENTURA, M. A. FERGUSON-SMITH, P. C. M. O'BRIEN, Y YONENAGA-YASSUDA \& M. J. J. SILVA, 2015. Comparative Chromosome Painting in Six Species of Oligoryzomys (Rodentia, Sigmodontinae) and the Karyotype Evolution of the Genus. PlosOne 10(2): e0117579. DOI: http://doi.org/10.1371/journal.pone.0117579

ESPINOSA, M. B. \& A. O. REIG, 1991. Cytogenetics and karyosystematics of South American Oryzomyine rodents (Cricetidae, Sigmodontinae) III. Banding karyotypes of Argentinean Oligoryzomys. Zeitschrift für Säugetierkund 56: 306-317.

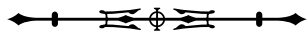


FAGUNDES, V., A. U. CHRISTOFF \& Y. YONENAGA-YASSUDA, 1998. Extraordinary chromosomal polymorphism with 28 different karyotypes in the neotropical species Akodon cursor (Muridae, Sigmodontinae), one of the smallest diploid number in rodents $(2 n=16,15$ and 14). Hereditas 129(3): 263-274. DOI: http://doi. org/10.1111/j.1601-5223.1998.00263.x

FARIA, M. B., 2008. Variação craniana e caracterização citogenética de Marmosops incanus (Lund 1840) (Didelphimorphia, Didelphidae) provenientes da Zona da Mata de Minas Gerais. Master thesis - Universidade Federal de Viçosa, Viçosa.

FARIA, M. B., M. L. G. SIQUEIRA \& C. R. BONVICINO, 2016. New record of the rare Atlantic Forest rodent Phyllomys lundi (Mammalia: Rodentia). Zoologia (Curitiba) 33(4): e20150208. DOI: http://doi.org/10.1590/S1984-4689zool-20150208

GALINDO-LEAL, C. \& I. G. CÂMARA, 2003. The Atlantic forest of South America: biodiversity status, threats and outlook. Island Press, Washington.

GARDNER, A., 2008 [2007]. Mammals of South America. Marsupials, xenarthrans, shrews, and bats: vol. 1. The University of Chicago Press, Chicago, Illinois.

GATTO DE ALMEIDA, F., 2015. Pequenos mamíferos não voadores do Parque Estadual Rio da Onça (Matinhos, PR): diversidade e morfologia. Master thesis - Universidade Federal do Paraná, Curitiba.

GEISE, L., 1995. Os roedores Sigmodontinae (Rodentia, Muridae) do estado do Rio de Janeiro. Sistemática, citogenética, distribuição e variação geográfica. PhD Dissertation - Universidade Federal do Rio de Janeiro, Rio de Janeiro.

GEISE, L., F. C. CANAVEZ \& H. N. SEUÁNEZ, 1998. Comparative karyology in Akodon (Rodentia, Sigmodontinae) from Southwestern Brazil. Journal of Heredity 89(2): 158-163. DOI: http://doi. org/10.1093/jhered/89.2.158

GEISE, L., L. G. PEREIRA, D. E. P. BOSSI \& H. G. BERGALLO, 2004. Pattern of elevational distribution and richness of non volant mammals in Itatiaia National Park and its surroundings, in Southeastern Brazil. Brazilian Journal of Biology 64(3b): 599-612. DOI: http://doi.org/10.1590/S1519-69842004000400007

GEISE, L., H. G. BERGALLO, C. E. L. ESBÉRARD, C. F. D ROCHA \& V. M. SLUYS, 2008. The karyotype of Blarinomys breviceps (Mammalia: Rodentia: Cricetidae) with comments on its morphology and some ecological notes. Zootaxa, Auckland 1907(1): 47-60. DOI: http://doi.org/10.11646/zootaxa.1907.1.3

GONÇALVES, P. R., F. C. ALMEIDA \& C. R. BONVICINO, 2005. A new species of Wiedomys (Rodentia: Sigmodontinae) from Brazilian Cerrado. Mammalian Biology 70(1): 46-60. DOI: http:// doi.org/10.1078/1616-5047-00175
GONÇALVES, P. R. \& J. A. OLIVEIRA, 2014. An integrative appraisal of the diversification in the Atlantic forest genus Delomys (Rodentia: Cricetidae: Sigmodontinae) with the description of a new species. Zootaxa 3760(1): 1-38. DOI: http://doi.org/10.11646/zootaxa.3760.1.1

GONÇALVES, P. R., A. U. CHRISTOFF, L. F. MACHADO, C. R. BONVICINO, F. B. PETERS \&A. R. PERCEQUILLO, 2020. Unraveling deep branches of the Sigmodontinae tree (Rodentia: Cricetidae) in Eastern South America. Journal of Mammalian Evolution 27: 139-160. DOI: http://doi.org/10.1007/s10914-018-9444-y

GOOGLE SCHOLAR [s. d.]. Available at: http://scholar.google.com. br. Accessed on: September 28, 2020.

GRAZZINI, G., 2014. Identidade e diversidade de pequenos mamíferos não voadores da Floresta Nacional de Piraí do Sul, Paraná, Brasil. Master Dissertation - Universidade Federal do Paraná, Curitiba.

GRAZZINI, G., C. M. MOCHI-JUNIOR, H. OLIVEIRA, J. S. PONTES, F. GATTO-ALMEIDA, I. J. SBALQUEIRO, I. HASS \& L. M. TIEPOLO, 2015. First record of Juliomys ossitenuis (Costa, Pavan, Leite and Fagundes, 2007) (Rodentia, Sigmodontinae) in Paraná state, southern Brazil. Check List 11(2): 1-5. DOI: http://doi. org/10.15560/11.2.1561

HAFFER, J., 1969. Speciation in Amazonian forest birds. Science 165(3889): 131-137. DOI: http://doi.org/10.1126/science.165.3889.131

HASS, I., S. MÜLLER, R. F. ARTONI \& I. J. SBALQUEIRO, 2011. Comparative chromosome maps of Neotropical rodents Necromys lasiurus and Thaptomys nigrita (Cricetidae) established by ZOO-FISH. Cytogenetic and Genome Research 135: 42-50. DOI: http://doi. org/10.1159/000330259

HERSHKOVITZ, P., 1987. History of the recent mammalogy of the Neotropical region from 1492 to 1850 . Fieldiana Zoology 39: 11-97.

HERSHKOVITZ, P., 1998. Report on some sigmodontine rodents collected in southeastern Brazil with descriptions of a new genus and six new species. Bonner Zoologische Beiträge 47: 193-256.

IPUCHA, M. C., M. D. GIMÉNEZ \& C. J. BIDAU, 2008. Heterogenity of the heterochromatin in six species of Ctenomys (Rodentia: Octondoitea: Ctenomyidae) from Argentina revealed by a combined analysis of C- and RE-banding. Acta Theriologica 53(1): 57-71. DOI: https://doi.org/10.1007/BF03194279

JANSA, S. A. \& R. S. VOSS, 2000. Phylogenetic studies on didelphid marsupials I. Introduction and preliminary results from nuclear IRBP gene sequences. Journal of Mammalian Evolution 7: 43-77. DOI: https://doi.org/10.1023/A:1009465716811

KASAHARA, S. \& Y. YONENAGA-YASSUDA, 1984. Um relatório de progresso de dados citogenéticos em roedores brasileiros. Revista Brasileira de Genética 7(3): 509-533.

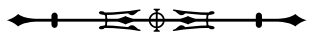


LEITE, Y. L., 2003. Evolution and systematics of the Atlantic Tree rats, genus Phyllomys (Rodentia, Echimyidae), with description of two new species. University of California Press (University of California Publications Zoology, 132), Berkeley.

LEITE, Y. L. \& A. C. LOSS, 2015. Genus Phyllomys Lund, 1839. In: J. L. PATTON, U. F. J. PARDIÑAS \& G. D'ELÍA (Ed.): Mammals of South América: vol. 2: Rodents: 915-928. The University of Chicago Press, Chicago, Illinois.

MAIA, V. \& A. LANGGUTH, 1981. New karyotypes of Brazilian Akodont rodents with notes on taxonomy. Zeitschrift Für Säugetierkunde 46: 241-249.

MATTEVI, M. S., I. J. SBALQUEIRO, T. R. O. DE FREITAS \& L. B. F. OLIVEIRA, 1982. Estudos citotaxonomicos em roedores do extremo sul do Brasil. Proceedings of the Congresso Latino Americano de Genética 5: 67.

MOCHI, J. T., 2014. Composição taxonômica e avaliação da diversidade da fauna de pequenos mamíferos não voadores na formação submontana do Parque Nacional Saint-Hilaire/Lange, Mata Atlântica Costeira do Paraná. Master thesis - Universidade Federal do Paraná, Postgraduate Program in Zoology, Curitiba.

MOREIRA, J. C., E. G. MANDUCA, P. R. GONÇALVES, J. R. M. M. MORAIS, R. P. PEREIRA, L. GEISE \& J. A. DERGAM, 2009. Small mammals from Serra do Brigadeiro State Park, Minas Gerais, southeastern Brazil: species composition and elevational distribution. Arquivos do Museu Nacional 67(1-2): 103-118.

MOREIRA, J. C. \& J. A. OLIVEIRA, 2011. Evaluating diversification hypotheses in the South American Cricetid Thaptomys nigrita (Lichtenstein, 1829) (Rodentia: Sigmodontinae): an appraisal of geographical variation based on different character systems. Journal of Mammalian Evolution 18: 201-214. DOI: https://doi.org/10.1007/ s10914-011-9155-0

MYERS, P. \& M. D. CARLETON, 1981. The species of Oryzomys (Oligoryzomys) in Paraguay and the identity of Azara's "Rat sixième ou Rat à Tarse Noir". University of Michigan (Miscellaneous Publications of the Museum of Zoology, 161), Ann Arbor.

NACHMAN, M. W. \& P. MYERS, 1989. Exceptional chromosomal mutations in a rodent population are not strongly underdominant. Proceedings of the National Academy of Sciences 86(17): 66666670. DOI: https://doi.org/10.1073/pnas.86.17.6666

PARDIÑAS, U. F. J., P. TETA \& G. D'ELÍA, 2009. Taxonomy and distribution of Abrawayaomys (Rodentia: Cricetidae), an Atlantic Forest endemic with the description of a new species. Zootaxa 2128(1): 39-60. DOI: https://doi.org/10.11646/zootaxa.2128.1.2

PARDIÑAS, U. F. J., P. TETA \& G. D'ELÍA, 2015. Genus Abrawayaomys F. Cunha and Cryz, 1979. In: J. L. PATTON, U. F. J. PARDIÑAS \& G. D'ELÍA (Ed.): Mammals of South América: vol. 2: Rodents: 73-75. The University of Chicago Press, Chicago, Illinois.
PARESQUE, R., W. P. SOUZA, S. L. MENDES \& V. FAGUNDES, 2004. Composição cariotípica da fauna de roedores e marsupiais de duas áreas da Mata Atlântica do Espírito Santo, Brasil. Boletim do Museu de Biologia Mello Leitão 17: 5-33.

PARESQUE, R., M. J. J. SILVA, Y. YONENAGA-YASSUDA \& V. FAGUNDES, 2007. Karyological geographic variation of Oligoryzomys nigripes Olfers, 1818 (Rodentia, Cricetidae) from Brazil. Genetics and Molecular Biology 30(1): 43-53. DOI: https://doi.org/10.1590/ S1415-47572007000100010

PARESQUE, R., A. U. CHRISTOFF \& V. FAGUNDES, 2009. Karyology of the Atlantic forest rodent Juliomys (Cricetidae): a new karyotype from southern Brazil. Genetics and Molecular Biology 32(2): 301-305. DOI: https://doi.org/10.1590/S141547572009005000031

PATTON, J. L., M. N. F. SILVA \& J. R. MALCOLM, 2000. Mammals of the Rio Juruá: Evolutionary and ecological diversification within Amazonia. Bulletin of the American Museum of Natural History (244): 1-306.

PATTON, J. L., U. F. J. PARDIÑAS \& G. D'ELÍA, 2015. Mammals of South América: vol. 2: Rodents. The University of Chicago Press, Chicago, Illinois.

PEREIRA, L. G. \& L. GEISE, 2007. Karyotype composition of some rodents and marsupials from Chapada Diamantina (Bahia, Brasil). Brazilian Journal of Biology 67(3): 509-518. DOI: https://doi. org/10.1590/S1519-69842007000300016

PEREIRA, L. G., L. GEISE, A. A. CUNHA \& R. CERQUEIRA, 2008. Abrawayaomys ruschii Cunha \& Cruz 1979 (Rodentia, Cricetidae) no Estado do Rio de Janeiro, Brasil. Papéis Avulsos de Zoologia 48(5): 33-40. DOI: https://doi.org/10.1590/S003110492008000500001

PEREIRA, N. P., K. VENTURA, J. R. M. C. SILVA, D. M. SILVA, Y. YONENAGA-YASSUDA \& K. C. M. PELLEGRINO, 2008. Karyotype characterization and nucleolar organizer regions of marsupial species (Didelphidae) from areas of Cerrado and Atlantic Forest in Brazil. Genetics and Molecular Biology 31(4): 887-892. DOI: https://doi.org/10.1590/S1415-47572008005000012

PINE, R. H. \& C. O. HANDLEY JR., 2008 [2007]. Genus Monodelphis Burnett, 1830. In: A. L. GARDNER (Ed.): Mammals of South America: vol. 1: Marsupials, xenarthrans, shrews, and bats: 82-107. The Chicago University Press, Chicago, Illinois.

POR, F. D., 1992. Sooretama: the Atlantic rain forest of Brazil. SPB Academic Publishing, The Hague, Austin.

POREMBSKI, S. \& W. BARTHLOTT (Ed.), 2000. Inselbergs biotic diversity of isolated rock outcrops in Tropical and Temperate region. Springer Verlag, Berlin Heidelberg, (Ecological Studies, v. 146), New York, Tokyo. DOI: https://doi.org/10.1007/978-3642-59773-2

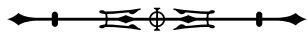


PORTO, T. J., A. C. CARNAVAL \& P. L. B. ROCHA, 2012. Evaluating forest refugial models using species distribution models, model filling and inclusion: a case study with 14 Brazilian species. Diversity and Distribution 19(3): 330-340. DOI: https://doi.org/10.1111/j.14724642.2012.00944.x

REIG, O. A., A. L. GARDNER, N. O. BIANCHI \& J. L. PATTON, 1977. The chromosomes of the Didelphidae (Marsupialia) and their evolutionary significance. Biological Journal of the Linnean Society 9(2): 191-216. DOI: https://doi.org/10.1111/j.1095-8312.1977.tb00265.x

SBALQUEIRO, I. J. \& A. P. NASCIMENTO, 1996. Occurrence of Akodon cursor (Rodentia, Cricetidae) with 14, 15 and 16 chromosome cytotypes in the same geographic area in Southern Brazil. Brazilian Journal of Genetics 19(4): 565-569. DOI: https://doi.org/10.1590/ S0100-84551996000400005

SBALQUEIRO, I. J., M. S. MATTEVI, L. F. B. OLIVEIRA \& T. R. O. FREITAS, 1982. Estudos cromossômicos de espécies de roedores akodontinos do Rio Grande do Sul. Ciência e Cultura 34: 750.

SBALQUEIRO, I. J., M. S. MATTEVI, L. F. OLIVEIRA \& M. J. V. SOLANO, 1991. B chromosome system in populations of Oryzomys flavescens (Rodentia, Cricetidae) from southern Brazil. Acta Theriologica 36: 193-199. DOI: https://doi.org/10.4098/AT.arch.91-18

SEABRIGHT, M., 1971. A rapid banding technique for human chromosomes. Lancet 298(7731): 971-972. DOI: https://doi. org/10.1016/S0140-6736(71)90287-X

SILVA, M. J. J. \& Y. YONENAGA-YASSUDA, 2004. B chromosomes in Brazilian rodents. Cytogenetics and Genome Research 106: 257263. DOI: https://doi.org/10.1159/000079296

SVARTMAN, M., 1989. Levantamento cariotípico de roedores da região do Distrito Federal. Master Thesis - Universidade de São Paulo, São Paulo.

TETA, P. \& U. F. J. PARDIÑAS, 2015. Genus Blarinomys Thomas, 1896. In: J. L. PATTON, U. F. J. PARDIÑAS \& G. D'ELÍA (Ed.): Mammals of South América: vol. 2: Rodents: 208-2011. The University of Chicago Press, Chicago, Illinois.

THOMAZINI, N. B., 2009. Correlação entre estrutura cariotípica e filogenia molecular em Rhipidomys (Cricetidae, Rodentia) do leste do Brasil. Master thesis - Universidade Federal do Espírito Santo, Vitória.

TORTATO, F. R., A. F. TESTONI \& S. L. ALTHOFF, 2014. Mastofauna terrestre da Reserva Biológica Estadual do Sassafrás, Doutor Pedrinho, Santa Catarina, Sul do Brasil. Biotemas 27(3): 123-129. DOI: http:// doi.org/10.5007/2175-7925.2014v27n3p123

VANZOLINI, P. E. \& E. E. WILLIAMS, 1970. South American anoles: the geographic differentiation and evolution of the Anolis chrysolepis species group (Sauria, Iguanidae). Arquivos de Zoologia 19(3-4): 125-298. DOI: http://doi.org/10.11606/issn.2176-7793. v19i3-4p125-298
VELOSO, H. P., A. L. R. RANGEL FILHO \& J. C. A. LIMA, 1991. Classificação da vegetação brasileira adaptada a um sistema universal. IBGE, Rio de Janeiro.

VENTURA, K., M. J. J. SILVA, V. FAGUNDES, R. PARDINI \& Y. YONENAGA-YASSUDA, 2004. An undescribed karyotype for Thaptomys $(2 n=50)$ and the mechanism of differentiation from Thaptomys nigrita $(2 \mathrm{n}=52)$ evidenced by FISH and Ag-NORs. Caryologia 57(1): 89-97. DOI: http://doi.org/10.1080/0008711 4.2004.10589376

VENTURA, K., M. J. J. SILVA \& Y. YONENAGA-YASSUDA, 2010. Thaptomys (Thomas 1915) (Rodentia, Sigmodontinae, Akodontini) with karyotypes $2 \mathrm{n}=50, \mathrm{FN}=48$ and $2 \mathrm{n}=52, \mathrm{FN}=52$ : two monophyletic lineages recovered by molecular phylogeny. Genetics and Molecular Biology 33(2): 256-261. DOI: http:// doi.org/10.1590/S1415-47572010005000053

VENTURA, K., Y. SATO-KUWABARA, V. FAGUNDES, L. GEISE, Y. L. R LEITE, L. P. COSTA \& M. J. J SILVA, 2012. Phylogeographic structure and karyotypic diversity of the Brazilian shrew mouse (Blarinomys breviceps, Sigmodontinae) in the Atlantic Forest. Cytogenetics and Genome Research 138(1): 31-35. DOI: http:// doi.org/10.1159/000341887

VENTURA, K., M. J. SILVA, L. GEISE, Y. L. R. LEITE, U. F. J. PARDIÑAS, Y. YONENAGA-YASSUDA \& G. D'ELÍA, 2013. The phylogenetic position of the enigmatic Atlantic Forest endemic spiny-mouse Abrawayaomys (Rodentia: Sigmodontinae). Zoological Studies 52: 55. DOI: http://doi.org/10.1186/1810522X-52-55

VOSS, R. S. \& S. A. JANSA, 2009. Phylogenetic relationships and classification of didelphid marsupials, an extant radiation of new world metatherian mammals. Bulletin of the American Museum of Natural History 32: 1-177. Available at: http://hdl.handle. net/2246/5975. Accessed on: September 28, 2020.

VOSS, R. S., D. P. LUNDE \& S. A. JANSA, 2005. On the contents of Gracilinanus Gardner and Creighton, 1989, with the description of a previously unrecognized clade of small didelphid marsupials. American Museum Novitates (3482): 1-34. DOI: http://doi. org/10.1206/0003-0082(2005)482[0001:OTCOGG]2.0.CO;2

WEB OF SCIENCE [s. d.]. Available at: https://webofknowledge. com. Accessed on: September 28, 2020.

WEKSLER, M. \& C. R. BONVICINO, 2005. Taxonomy of pigmy rice rat genus Oligoryzomys Bangs, 1900 (Rodentia, Sigmodontinae) of the Brazilian Cerrado, with the description of two new species. Arquivos do Museu Nacional 63: 113-130.

WEKSLER, M., E. M. S. LEMOS, P. S. D'ANDREA \& C. R. BONVICINO, 2017. The taxonomic status of Oligoryzomys mattogrossae (Allen 1916) (Rodentia: Cricetidae: Sigmodontinae), reservoir of Anajatuba hantavirus. American Museum Novitates (3880): 1-32. DOI: http://doi.org/10.1206/3880.1

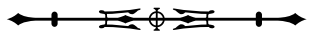


WOLF, R. W., R. V. ROSSI, M. ARAGONA \& D. M. AGUIARA, 2016. First record of Pseudoryzomys simplex (Cricetidae, Sigmodontinae) in a flooded area of the Pantanal, Brazil. Brazilian Journal of Biology 76(4): 1054-1057. DOI: http://doi.org/10.1590/1519-6984.09015

YAZBECK, G. M., R. L. BRANDÃO, H. M. CUNHA\&A. P. PAGLIA, 2011. Detection of two morphologically cryptic species from the cursor complex (Akodon spp.; Rodentia, Cricetidae) through the use of RAPD markers. Genetic and Molecular Research 10(4): 2881 2892. DOI: http://doi.org/10.4238/2011.November.22.2

YONENAGA, Y., 1972. Chromosomal polymorphism in the rodent Akodon arviculoides ssp. $(2 n=14)$ resulting from two pericentric inversions. Cytogenetics 11: 488-499. DOI: http://doi. org/10.1159/000130215

YONENAGA, Y., 1975. Karyotypes and chromosome polymorphism in Brazilian rodents. Caryologia 28: 269-286. DOI: http://doi.org/1 $0.1080 / 00087114.1975 .10796617$

YONENAGA, Y., S. KASAHARA, E. J. C. ALMEIDA \& A. L. PERACCHI, 1975. Chromosomal banding patterns in Akodon arviculoides $(2 n=14)$, Akodon sp. $(2 n=24$ and 25$)$ and two hybrids with 19 chromosomes. Cytogenetics and Cell Genetics 15: 388399. DOI: http://doi.org/10.1159/000130538

YONENAGA, Y., O. FROTA-PESSOA, S. KASAHARA \& E. J. C. ALMEIDA, 1976. Cytogenetic studies on Brazilian rodents. Ciência e Cultura 28: 202-211.
YONENAGA-YASSUDA, Y., 1979. New karyotypes and somatic and germ-cell banding in Akodon arviculoides (Rodentia, Cricetidae). Cytogenetics and Cell Genetics 23(4): 241-249. DOI: https://doi. org/10.1159/000131334

YONENAGA-YASSUDA, Y., M. L'ABBATE \& T. H. CHU, 1983. Bandas de alta resolução e padrões de replicação do cromossomo $X$ no gênero Akodon. Ciência e Cultura 35: 680.

ZANCHIN, N. I. T., 1988. Estudos cromossômicos em orizominos e equimídeos da Mata Atlântica. Master thesis - Universidade Federal do Rio Grande do Sul, Postgraduate Program in Genetics and Molecular Biology, Porto Alegre.

ZANCHIN, N. I. T., A. LANGGUTH \& M. S. MATTEVI, 1992a. Karyotypes of Brazilian species of Rhipidomys (Rodentia, Cricetidae). Journal of Mammalogy 73(1): 120-122. DOI: http:// doi.org/10.2307/1381872

ZANCHIN, N. I. T., I. J. SBALQUEIRO, A. LANGGUTH, R. C. BOSSLE, E. C. CASTRO, L. F. B. OLIVEIRA \& M. S. MATTEVI, 1992b. Karyotype and species diversity of the genus Delomys (Rodentia, Cricetidae) in Brazil. Acta Theriologica, Białowieża 37: 163-169. DOI: http://doi.org/10.4098/AT.arch.92-16

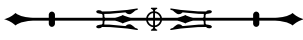

